\title{
Effects of D-a-tocopherol and dietary energy on growth and health of preruminant dairy calves
}

\author{
L. A. Krueger, ${ }^{*}$ D. C. Beitz, ${ }^{* 1}$ K. Onda, ${ }^{*}$ M. Osman, ${ }^{*}$ M. R. O'Neil, ${ }^{*}$ S. Lei, ${ }^{*}$ F. H. Wattoo, ${ }^{*}$ R. L. Stuart, $†$ \\ H. D. Tyler, ${ }^{*}$ and B. Nonneckeł \\ *Department of Animal Science, lowa State University, Ames 50011 \\ †Stuart Products Inc., Bedford, TX 76022 \\ †Ruminant Diseases and Immunology Research Unit, National Animal Disease Center, Agricultural Research Service, USDA, Ames, IA 50010
}

\section{ABSTRACT}

To observe the effects of supplemental dietary $\mathrm{D}-\alpha-$ tocopherol in relation to dietary energy on growth and immune status in dairy calves, 32 newborn Holstein bull calves were assigned to 1 of 4 treatments for $5 \mathrm{wk}$ in a $2 \times 2$ factorial, randomized complete block, split-plot design. Calves received moderate growth (MG) or low growth (LG) all-milk dietary treatments, formulated to support daily gains of 0.5 or $0.25 \mathrm{~kg} / \mathrm{d}$, respectively, per the dietary energy recommendation for milk-fed calves according to the National Research Council's Nutrient Requirements of Dairy Cattle. Calves in both groups were either injected i.m. with Vital E-A+D (injectable solution of vitamins $\mathrm{E}, \mathrm{A}$, and $\mathrm{D}$ ) on $\mathrm{d} 1$ and supplemented with Emcelle Tocopherol (micellized vitamin E) via milk daily (MG-S and LG-S), or were not supplemented (MG-C and LG-C) during the study period. Total weight gain of $M G$ calves was greater than that of LG calves and tended to be greater in MG-S calves than in MG-C calves. Calves receiving vitamin supplementation demonstrated greater concentrations of plasma $\alpha$-tocopherol, retinol, and 25- $(\mathrm{OH})$-vitamin $\mathrm{D}$ than did control calves, whereas MG calves demonstrated a lower concentration of plasma $\alpha$-tocopherol than did LG calves. The apparent increased utilization of $\alpha$-tocopherol by MG calves was accompanied by a rise in serum haptoglobin, a positive acute-phase protein and indicator of inflammation, especially in MG-C calves. Serum amyloid A, also a positive acutephase protein, was not different among groups, but was elevated from baseline in all groups during wk 1 through 3. Plasma $\operatorname{IgG}_{1}$ concentrations were higher in MG-S and LG-S calves than in their nonsupplemented dietary counterparts, whereas plasma $\operatorname{IgG}_{2}, \operatorname{Ig} \mathrm{A}$, and IgM concentrations were not different among groups. In summary, dietary supplementation of $\mathrm{D}-\alpha$-tocopherol

Received July 29, 2013.

Accepted February 17, 2014.

${ }^{1}$ Corresponding author: dcbeitz@iastate.edu improved plasma $\alpha$-tocopherol status and tended to increase growth in calves fed for $0.5 \mathrm{~kg}$ of average daily gain. Vitamin supplementation ameliorated the rise of serum haptoglobin associated with acute inflammation in MG calves, and may have improved passive transfer of maternal antibody. These results indicate a role for $\alpha$-tocopherol in prevention of proinflammatory state associated with greater dietary energy and onset of infectious disease.

Key words: tocopherol, growth, haptoglobin, dairy calf

\section{INTRODUCTION}

Vitamin E has gained popularity in nutritional studies in recent years because of its known antioxidative properties and potential health benefits in several biological functions, including immunity, metabolism, and tissue longevity. Although the antioxidative role of vitamin E is largely undisputed and additional mechanisms have been explored by which vitamin E modulates adaptive immune responses, no overwhelming consensus has been reached concerning the effects of form and source of vitamin $\mathrm{E}$ on food animal performance and the required level of dietary vitamin E supplementation.

The most biologically active form of vitamin $\mathrm{E}$ is $\alpha$-tocopherol, which is available from natural and synthetic nonester and esterified sources. RRR- $\alpha-$ Tocopherol (D- $\alpha$-tocopherol) is the natural stereoisomer and has the highest biological activity, and allrac- $\alpha$-tocopherol (DL- $\alpha$-tocopherol) is the synthetic source of $\alpha$-tocopherol. Synthetic supplements provide a racemic mixture of 8 stereoisomers, including the less bioavailable SSS- and 2S- forms. Natural and synthetic supplements may be of nonester form, especially when administered to neonates that lack sufficient pancreatic lipase to cleave the ester and thereby use the $\alpha$-tocopherol more effectively. Bioactivity, distinguished from bioavailability by the measureable effect on a clinical endpoint (Jensen and Lauridsen, 2007), has been established for both ester and nonester forms 
of RRR- $\alpha$ - and all-rac- $\alpha$-tocopherol based on a series of rat resorption-gestation tests by Weiser and Vecchi $(1981,1982)$. Bioactivity of the acetate ester of synthetic $\alpha$-tocopherol is defined in international units, with $1 \mathrm{IU}$ being equivalent to $1 \mathrm{mg}$ of all-rac- $\alpha$-tocopheryl acetate. All-rac- $\alpha$-tocopherol has a bioactivity of 1.10 IU, RRR- $\alpha$-tocopheryl acetate has a bioactivity of 1.36 $\mathrm{IU}$, and RRR- $\alpha$-tocopherol has a bioactivity of $1.49 \mathrm{IU}$ per mg (Voljc et al., 2011).

The antioxidative and immunoregulatory benefits of $\mathrm{D}$ - $\alpha$-tocopherol supplementation are of interest to commercial dairy calf operations seeking to maximize growth and minimize morbidity. Diets utilizing both carbohydrates and fats as primary energy sources support both lean tissue accretion and fat deposition (Diaz et al., 2001; Tikofsky et al., 2001), and elevated dietary protein linearly increases ADG, gain-to-feed ratio, and lean tissue accretion (Blome et al., 2003). However, greater inclusion of energy in the diet of the preruminant calf causes concern regarding the negative effects of increased oxidative stress, especially on immune function. Nonnecke et al. (2003) reported higher nitric oxide and lower IFN- $\gamma$ production from mononuclear leukocytes of calves fed for $1.2 \mathrm{~kg}$ of ADG relative to calves fed for $0.55 \mathrm{~kg}$ of ADG, and Foote et al. (2007) documented decreased $\mathrm{T}$ lymphocyte viability in calves fed for similar growth. These results indicate that the inclusion rate of energy in diet may affect cell-mediated immunity in calves.

To learn if a possible interaction exists among $\alpha$-tocopherol status, immune status, and growth performance of the preruminant calf, micellized $\mathrm{D}-\alpha$-tocopherol was supplemented to calves via diets that limited energy, $\alpha$-tocopherol, or both energy and $\alpha$-tocopherol. In addition to weight gain, the positive acute-phase proteins serum amyloid A (SAA) and haptoglobin were quantified as markers of inflammatory status of the calves during the study period. Our hypothesis was that micellized D- $\alpha$-tocopherol supplementation would improve $\alpha$-tocopherol status, resulting in improvements in growth performance and immune status as indicated by markers of acute systemic inflammation.

\section{MATERIALS AND METHODS}

\section{Animals and Diets}

Calf-related procedures were approved by the Animal Care and Use Committee of Iowa State University. Holstein bull calves $(\mathrm{n}=32)$ were selected randomly from the Iowa State University dairy herd. Day of birth was designated as $\mathrm{d} 0$ for each calf. The date of $\mathrm{d} 0$ ranged from April 1, 2012, to June 7, 2012. On d 0, calves received 1 feeding of $3.8 \mathrm{~L}$ of colostrum immediately postpartum and navels were dipped in $7.0 \%$ iodine solution (Midwest Veterinary Supply, Burnsville, MN). Calves were housed in individual pens $(1.2 \times 1.8 \mathrm{~m})$ inside a hoop barn $(15.2 \times 39.0 \mathrm{~m})$ at the Iowa State University dairy farm. Pen floors were formed with sand approximately $15 \mathrm{~cm}$ above the normal barn floor and were bedded with straw daily.

Calves were assigned randomly to 1 of 4 dietary treatments in a $2 \times 2$ factorial, randomized complete block, split-plot design. Calves received 1 of 2 all-milk dietary treatments, formulated for moderate growth (MG) of $0.5 \mathrm{~kg} / \mathrm{d}$ or low growth $(\mathbf{L G})$ of $0.25 \mathrm{~kg} / \mathrm{d}$ according to the dietary energy recommendation for "Young Replacement Calves Fed Only Milk or Milk Replacer" by the NRC (2001). The MG and LG calves were fed 2.85 and $1.99 \mathrm{~L}$, respectively, of pasteurized whole milk twice daily via bottles. Milk composition (Dairy Lab Services, Dubuque, IA) is summarized in Table 1. Ad hoc milk samples $(>5 \mathrm{~mL} ; \mathrm{n}=5)$ were collected approximately every 4 wk for quantification of vitamins $\mathrm{A}$ and $\mathrm{E}$ according to the procedure described by Stahr (1991). Vitamin D content in dietary milk was assumed to be held constant at $307 \mathrm{IU} / \mathrm{kg}$ of DM (NRC, 2001). Content of vitamins $\mathrm{A}$ and $\mathrm{E}$ in dietary milk is summarized in Table 2. Calves were not offered additional hay or grain, and water was offered ad libitum.

Calves in these 2 dietary energy groups were either supplemented (MG-S and LG-S) with vitamins E, A, and D or not supplemented (MG-C and LG-C) as a control. Vitamin E-supplemented calves were injected i.m. on d 0 with $5 \mathrm{~mL}$ of vitamin $\mathrm{E}$, A, and $\mathrm{D}$ solution

Table 1. Composition of dietary milk summarized by month,

\begin{tabular}{lcccc}
\hline \multicolumn{4}{c}{ Milk component } \\
\cline { 2 - 5 } & $\begin{array}{c}\text { Butter-fat } \\
\text { percentage, } \\
\text { of whole milk }\end{array}$ & $\begin{array}{c}\text { Protein } \\
\text { percentage, } \\
\text { of whole milk }\end{array}$ & $\begin{array}{c}\text { SCC, } \\
\times 10^{3} \text { cells } / \mathrm{mL}\end{array}$ & $\begin{array}{c}\text { MUN, } \\
\text { month } / \mathrm{dL}\end{array}$ \\
\hline March & 4.56 & 3.11 & 1,898 & 10.9 \\
April & 3.35 & 3.19 & 1,479 & 7.2 \\
May & 4.17 & 3.14 & 1,643 & 12.67 \\
June & 3.26 & 3.32 & 1,032 & 10.6 \\
July & 3.90 & 3.29 & 695 & 14.3 \\
\hline
\end{tabular}


Table 2. Vitamin A and E content in dietary milk

\begin{tabular}{lcc}
\hline & \multicolumn{2}{c}{ Analysis, $\mu \mathrm{g} / \mathrm{mL}$} \\
\cline { 2 - 3 } Week & Vitamin A & Vitamin E \\
\hline 0 & $<0.1$ & 1.2 \\
4 & $<0.1$ & 1.0 \\
8 & $<0.1$ & 0.7 \\
11 & $<0.1$ & 0.7 \\
14 & $<0.1$ & 1.1 \\
\hline
\end{tabular}

containing $300 \mathrm{IU}$ of vitamin E, 100,000 IU of vitamin $\mathrm{A}$, and 10,000 IU of vitamin $\mathrm{D}_{3}$ per milliliter (Vital E-A+D, Stuart Products Inc., Bedford, TX) and daily administered 500 IU of D- $\alpha$-tocopherol (Emcelle Tocopherol, $500 \mathrm{IU} / \mathrm{mL}$, Stuart Products Inc.) via milk at $0800 \mathrm{~h}$. Control calves were not supplemented during the study period.

\section{BW Measurement and Blood Sample Collection}

Body weight was measured and recorded at birth for each calf and measured again each week for 5 wk. Body weights were measured approximately $60 \mathrm{~min}$ after the morning feeding. Blood samples were collected by jugular venipuncture on $\mathrm{d} 0$. Blood draw time relative to birth ranged from $3 \mathrm{~h}$ postpartum and before colostrum feeding to $22 \mathrm{~h}$ postpartum and after colostrum feeding. Blood samples were taken by venipuncture again each week at approximately $90 \mathrm{~min}$ following the morning milk feeding. Samples $(10 \mathrm{~mL})$ were collected in Vacutainer tubes (Becton, Dickinson and Company, Franklin Lakes, NJ) for subsequent quantification of serum haptoglobin, SAA, serum $\operatorname{IgG}_{1}, \operatorname{IgG}_{2}$, IgA, IgM, plasma $\alpha$-tocopherol, 25-(OH)-vitamin $\mathrm{D}$, retinol, glucose, and NEFA.

\section{Quantification of Serum Proteins}

Serum haptoglobin concentrations $(\mu \mathrm{g} / \mathrm{mL})$ were determined via a bovine-specific haptoglobin ELISA (Immunology Consultants Laboratory Inc., Newberg, OR), as described by Nonnecke et al. (2012). Serum amyloid A $(\mu \mathrm{g} / \mathrm{mL})$ concentrations were determined via a multispecies SAA ELISA kit (Tridelta Development Ltd., Maynooth, Co. Kildare, Ireland) according to manufacturer's instructions. Immunoglobulin isotype concentrations $(\mathrm{mg} / \mathrm{mL})$ were quantified by capture ELISA, as described by Nonnecke et al. (2012).

\section{Quantification of Plasma Vitamins}

Plasma $\alpha$-tocopherol and retinol analyses were conducted by the Veterinary Diagnostic Laboratory (College of Veterinary Medicine, Iowa State University) according to procedures described by Stahr (1991). $25-(\mathrm{OH})-$ Vitamin D was quantified by Heartland Assays (Ames, IA) using an equilibrium radioimmunoassay procedure (Hollis et al., 1993) after the extraction of $25-(\mathrm{OH})$-vitamin $\mathrm{D}$ with acetonitrile.

\section{Quantification of Plasma Glucose and NEFA}

Plasma glucose $(\mathrm{mg} / \mathrm{dL})$ was quantified by using a commercial assay (Autokit Glucose Kit, Wako Diagnostics, Richmond, VA) according to manufacturer's instructions. Nonesterified fatty acids $(\mu \mathrm{g} / \mathrm{mL})$ were quantified by using the HR Series NEFA-HR-(2) Kit (Wako Diagnostics) according to manufacturer's instructions.

\section{Statistical Analysis}

Data were analyzed as a $2 \times 2$ factorial, randomized complete block, split-plot design using mixed procedures of SAS (version 9.3, SAS Institute Inc., Cary, NC). Calf served as the experimental unit for all analyses. Units were blocked within each treatment group by order of birth. The model included main effects of energy, vitamin, time, and all possible interactions of main effects. The energy-by-vitamin-by-block interaction was included as a random effect. Birth weight and total serum Ig concentration at wk 1 were initially used as covariates but were not found to be significant; therefore, these covariates were not used in the final model. Least squares means were compared via the PDIFF statement in SAS, and $P$-values were adjusted by the Tukey-Kramer method. Post hoc analyses were triggered when main effects exhibited a strong trend $(P<0.1)$. Means were considered different when $P<$ 0.05. Results are reported as least squares means \pm SEM. To test the hypothesis that vitamin supplementation increased weight gain in calves fed calorically adequate diets only, ADG of MG-C and MG-S calves were analyzed via an ad hoc 2-sample, 1-tailed Student's $t$-test, using SAS. Data are reported as means \pm SEM.

\section{RESULTS}

Preruminant dairy calves were subject to mild nutritional stress and supplemented with $\mathrm{D}-\alpha$-tocopherol under the hypothesis that improved $\alpha$-tocopherol status would strengthen immune defenses and improve growth rate and health. Weight gain was used as a measure of growth rate. Positive acute-phase proteins SAA and haptoglobin, as well as $\operatorname{IgG}_{1}, \operatorname{IgG}_{2}, \operatorname{IgA}$, and $\operatorname{IgM}$, were quantified as measures of immune status. The main statistical effects are summarized in Table 3. 
Table 3. Significance of main effects and interactions of main effects

\begin{tabular}{|c|c|c|c|c|c|c|c|}
\hline \multirow[b]{2}{*}{$\begin{array}{l}\text { Response } \\
\text { variable }\end{array}$} & \multicolumn{7}{|c|}{$P$-value ${ }^{1}$} \\
\hline & $\begin{array}{c}\text { Energy } \times \\
\text { Vitamin } \times \\
\text { Time }\end{array}$ & $\begin{array}{l}\text { Energy } \\
\times \text { Time }\end{array}$ & $\begin{array}{l}\text { Vitamin } \\
\times \text { Time }\end{array}$ & $\begin{array}{c}\text { Energy } \\
\times \text { Vitamin }\end{array}$ & Energy & Vitamin & Time \\
\hline Weight gain & 0.0005 & NS & 0.053 & 0.016 & NS & NS & $<0.0001$ \\
\hline Serum vitamin E & $\mathrm{NS}$ & NS & $<0.0001$ & NS & 0.048 & $<0.0001$ & $<0.0001$ \\
\hline Serum vitamin A & NS & 0.002 & 0.009 & NS & 0.056 & NS & $<0.0001$ \\
\hline Serum amyloid A & NS & NS & NS & NS & NS & NS & $<0.0001$ \\
\hline IgG1 & 0.002 & 0.068 & 0.002 & NS & NS & NS & $<0.0001$ \\
\hline IgG2 & 0.076 & 0.018 & NS & NS & NS & NS & 0.008 \\
\hline IgA & NS & NS & NS & NS & NS & NS & $<0.0001$ \\
\hline IgM & 0.068 & NS & NS & 0.054 & NS & NS & $<0.0001$ \\
\hline Glucose & NS & NS & NS & 0.086 & NS & NS & $<0.0001$ \\
\hline NEFA & 0.0005 & NS & 0.053 & 0.016 & NS & NS & $<0.0001$ \\
\hline
\end{tabular}

${ }^{1} P$-value associated with type 3 test of fixed effects in Proc Mixed of SAS (SAS Institute Inc., Cary, NC).

\section{Weight Gain}

Weight gain of calves in all treatment groups is shown in Figure 1. Weight gain of MG calves, irrespective of vitamin supplementation, was greater $(P<0.0001)$ than that of LG calves. Mean birth weights of calves in all treatment groups were similar. The time-by-energytreatment interaction was significant $(P<0.05)$ and revealed that gain of MG calves plateaued at wk 2, indicating weight gain for MG calves was similar to weight gain for LG calves through wk 3 . By wk 4 and 5 , weight gains of MG calves exceeded $(P<0.0001)$ those of $\mathrm{LG}$ calves. Weight gains of MG and LG calves by wk 5 were $14.6 \pm 0.7$ and $8.8 \pm 0.7 \mathrm{~kg}$, respectively.

Vitamin supplementation tended to increase $(P=$ 0.066) ADG in MG calves but not in LG calves. Average daily gain for MG-S calves was $0.47 \pm 0.07 \mathrm{~kg}$, whereas average daily gain for MG-C calves was $0.41 \pm$ $0.08 \mathrm{~kg}$. Final mean weight gains for MG-S and MG-C calves were $15.4 \pm 1.1$ and $13.8 \pm 1.0 \mathrm{~kg}$, respectively.

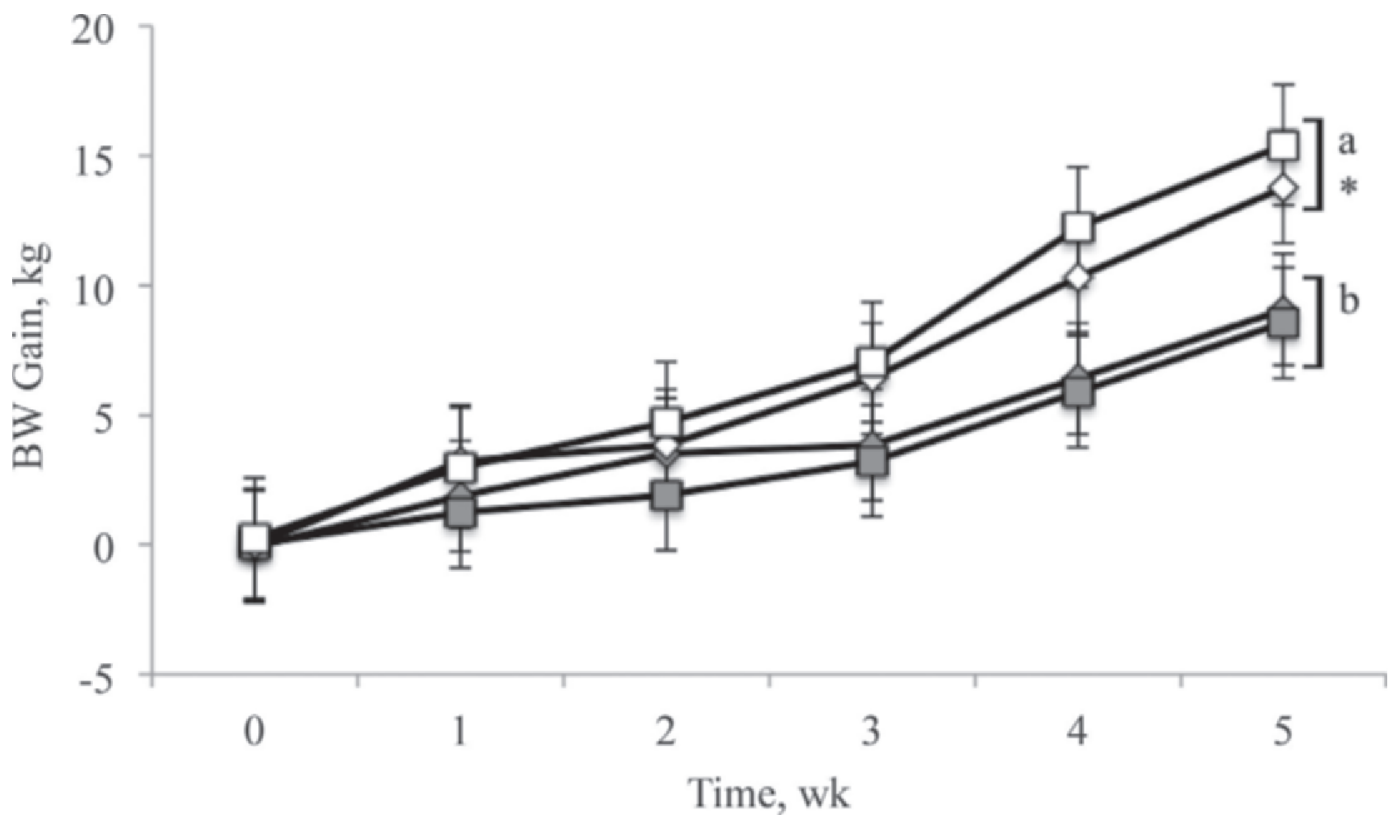

Figure 1. Body weight gain of calves during the experimental period. Calves were fed all-milk diets formulated to support daily gains of 0.25 (LG) and $0.5(\mathrm{MG}) \mathrm{kg}$ and supplemented (S) or not supplemented (C) with vitamins A, D, and E, creating 4 treatment groups: LG-C ( $)$, LG-S $(\square)$, MG-C $(\diamond)$, and MG-S $(\square)$. An asterisk $(*)$ indicates that ADG of MG-S and MG-C calves are different $(P=0.066)$. Brackets with different letters $(\mathrm{a}, \mathrm{b})$ denote pooled means that are different $(P<0.0001)$. Week 0 equals the date of birth. Values are mean \pm SEM; $\mathrm{n}=32$. 


\section{Fat-Soluble Vitamin Status}

$D-\alpha-$ Tocopherol supplementation proved to be effective in increasing plasma $\alpha$-tocopherol concentrations. Plasma $\alpha$-tocopherol concentrations of calves in all treatment groups are shown in Figure 2a. Plasma $\alpha$-tocopherol was affected by a time-by-vitamintreatment interaction $(P<0.0001$; Figure $2 \mathrm{~b})$ and by energy treatment $(P<0.05$; Figure 2c). Plasma $\alpha$-tocopherol concentrations of all calves were similar at wk 0 , but supplemented calves already exhibited higher $(P<0.02)$ concentrations of $\alpha$-tocopherol than did control calves by wk $1(4,196 \pm 485$ and 1,590 \pm $476 \mathrm{ng} / \mathrm{mL}$, respectively). Daily supplementation with $D$ - $\alpha$-tocopherol had an accumulating effect such that the mean concentration in supplemented calves at wk 5 $(7,759 \pm 485)$ was higher $(P<0.0001)$ than the mean concentration at wk 1 . Control calves exhibited plasma $\alpha$-tocopherol concentrations that remained unchanged and relatively low during the 5 -wk study.

Plasma $\alpha$-tocopherol concentrations were higher $(P$ $<0.41$ ) in LG than in MG calves from wk 2 to 5 , especially when supplemented with $\mathrm{D}-\alpha$-tocopherol. Although the time-by-energy-treatment interaction was not significant $(P=0.23)$, plasma $\alpha$-tocopherol concentrations of $\mathrm{MG}$ and $\mathrm{LG}$ calves differed $(P=0.17)$ at wk $2(2,499 \pm 493$ and $4,450 \pm 504 \mathrm{ng} / \mathrm{mL}$ for $\mathrm{MG}$ and $\mathrm{LG}$ calves, respectively) and remained different $(P<0.41)$ through the duration of the study (Figure 2c). Overall, mean plasma $\alpha$-tocopherol concentration of MG calves during the 5 -wk period was less $(P<0.05)$ than that of LG calves $(2,477 \pm 281$ and $3,556 \pm 296 \mathrm{ng} / \mathrm{mL}$, respectively).

Effects of the injectable treatment on plasma 25- $(\mathrm{OH})$-vitamin D concentrations are shown in Figure 3 . Both the week-by-vitamin and week-by-energy treatment interactions were significant. As shown in Figure 3 b, supplemented calves exhibited higher $(P<0.0005)$ concentrations relative to wk 0 by wk 1 ( $21.3 \pm 2.9$ vs. $41.0 \pm 2.9 \mathrm{ng} / \mathrm{mL}$, respectively). After wk 1, plasma 25-(OH)-vitamin D of supplemented calves steadily decreased $(P<0.0001)$ to a wk-5 concentration of 15.8 $\pm 2.9 \mathrm{ng} / \mathrm{mL}$. Concentrations in control calves steadily decreased $(P<0.0005)$ during the study, and by wk 5 the mean concentration was $7.6 \pm 2.6 \mathrm{ng} / \mathrm{mL}$. Mean concentrations in both LG and MG calves decayed below $25 \mathrm{ng} / \mathrm{mL}$ by wk 2 and below $15 \mathrm{ng} / \mathrm{mL}$ by wk 5 (Figure 3c).

Plasma retinol concentrations are shown in Figure 4a. Injected calves exhibited higher $(P<0.0005)$ concentrations relative to wk 0 by wk 1 (109.6 \pm 23.0 vs. $265.9 \pm 23.0 \mathrm{ng} / \mathrm{mL}$, respectively). Plasma retinol in supplemented calves numerically decreased $(P=0.25)$ after wk 1 and was similar at wk 2 to wk 0 , but then a.

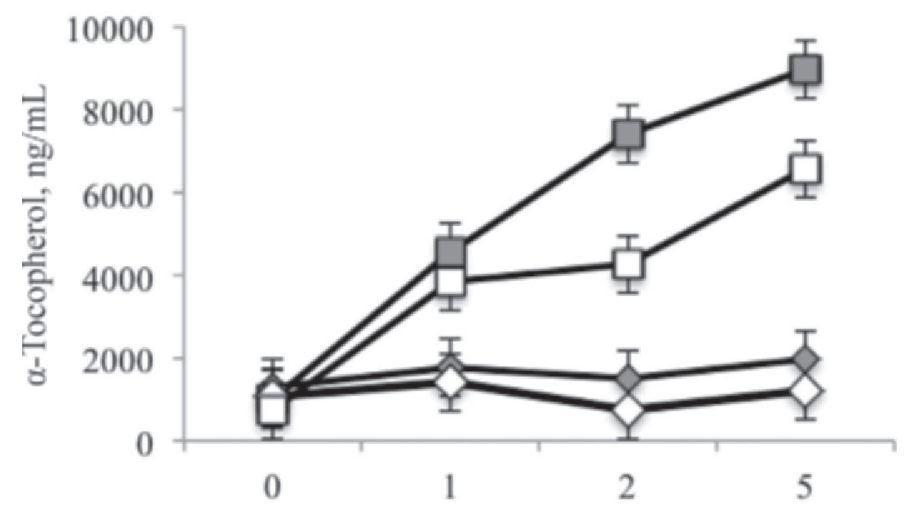

b.
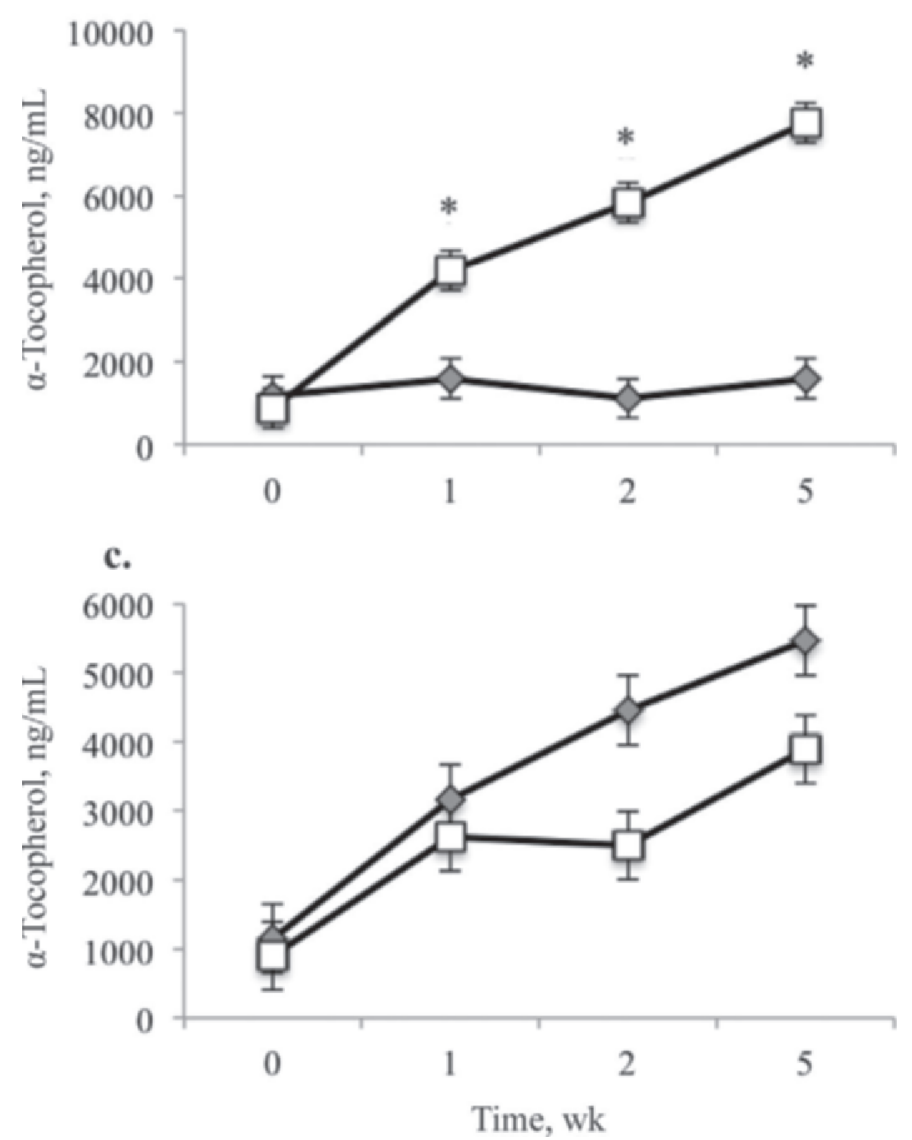

Figure 2. Plasma $\alpha$-tocopherol concentrations of calves during the experimental period. (a) Calves were fed all milk diets formulated to support daily gains of 0.25 (LG) and 0.5 (MG) and supplemented $(\mathrm{S})$ or not supplemented (C) with vitamins A, D, and E, creating 4 treatment groups: LG-C $(\diamond)$, LG-S $(\boldsymbol{\square})$, MG-C $(\diamond)$, and MG-S $(\square)$. (b) Calves were supplemented (S) or not supplemented (C) with vitamins A, D, and E; C ( ), S ( $\square$ ). (c) Calves were fed all-milk diets formulated to support daily gains of 0.25 (LG) and 0.5 (MG) $\mathrm{kg}$; LG $(\diamond)$, MG $(\square)$. An asterisk $\left({ }^{*}\right)$ signifies means within the same week are different $(P<0.05)$. Week 0 equals date of birth. Values are mean $\pm \mathrm{SEM} ; \mathrm{n}=32$. 
a.

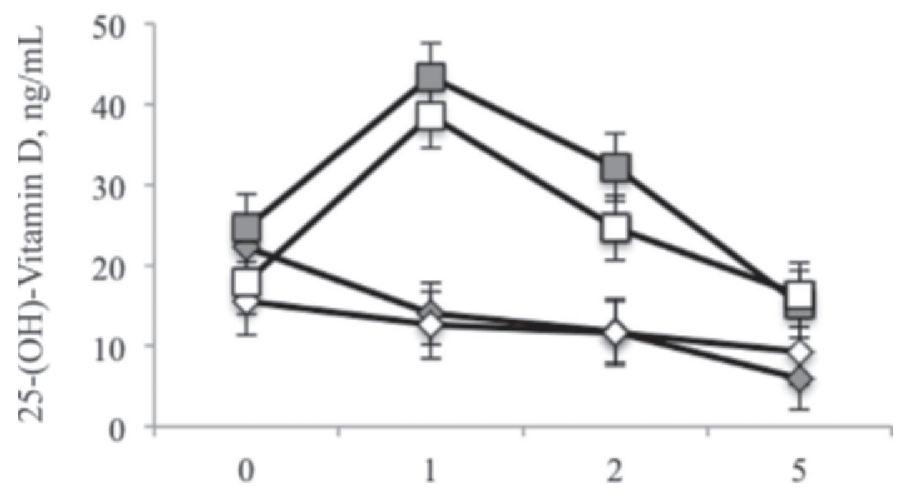

b.

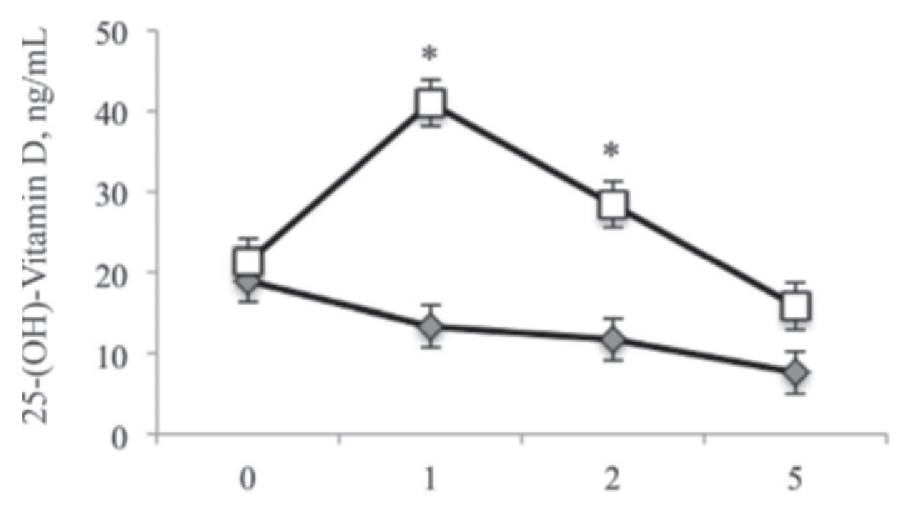

c.

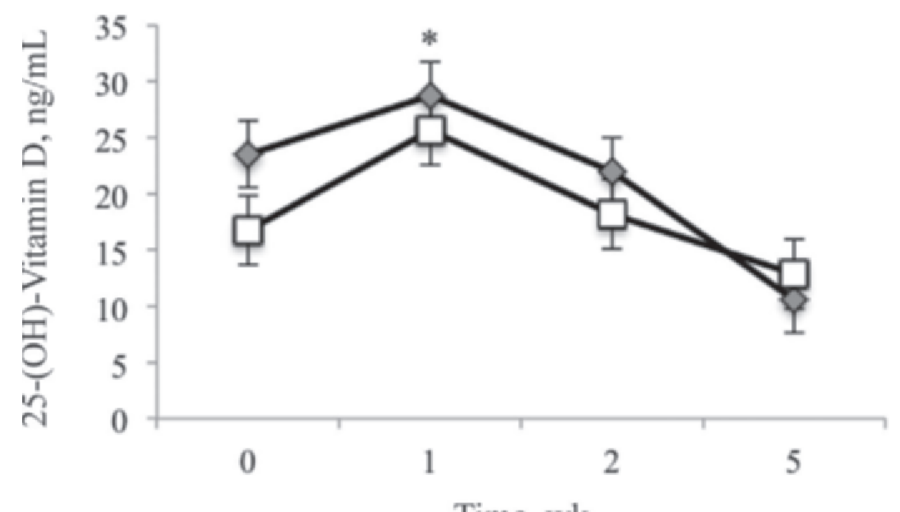

Time, wk

Figure 3. Plasma 25-(OH)-vitamin D concentrations of calves during the experimental period. (a) Calves were fed all-milk diets formulated to support daily gains of 0.25 (LG) and 0.5 (MG) $\mathrm{kg}$ and supplemented $(\mathrm{S})$ or not supplemented $(\mathrm{C})$ with vitamins $\mathrm{A}, \mathrm{D}$, and E, creating 4 treatment groups: LG-C $(\diamond)$, LG-S $(\boldsymbol{\square})$, MG-C $(\diamond)$, and MG-S ( $\square$ ). (b) Calves were supplemented (S) or not supplemented (C) with vitamins A, D, and E; C $(\diamond), \mathrm{S}(\square)$. (c) Calves were fed all-milk diets formulated to support daily gains of $0.25(\mathrm{LG})$ and $0.5(\mathrm{MG})$ $\mathrm{kg}$; LG $(\diamond)$, MG $(\square)$. An asterisk $(*)$ denotes means within the same week are different $(P<0.05)$. Week 0 equals date of birth. Values are mean $\pm \mathrm{SEM} ; \mathrm{n}=32$. a.

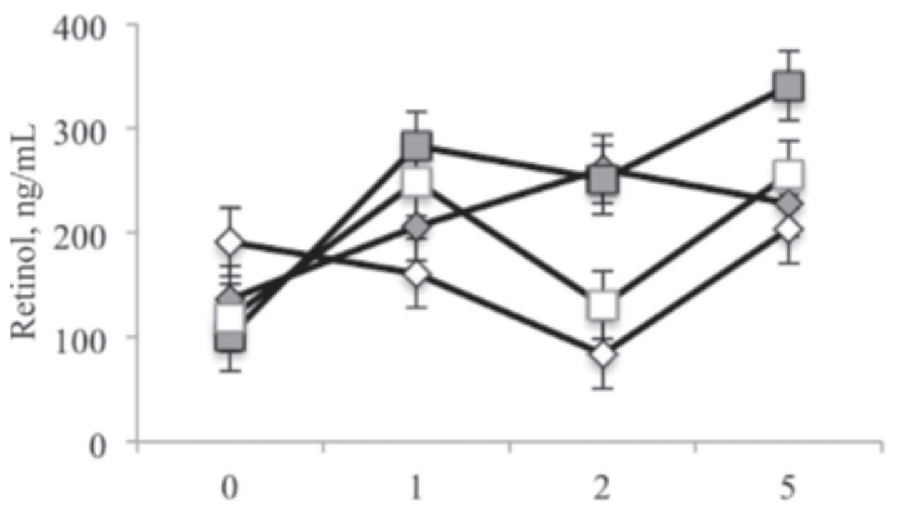

b.

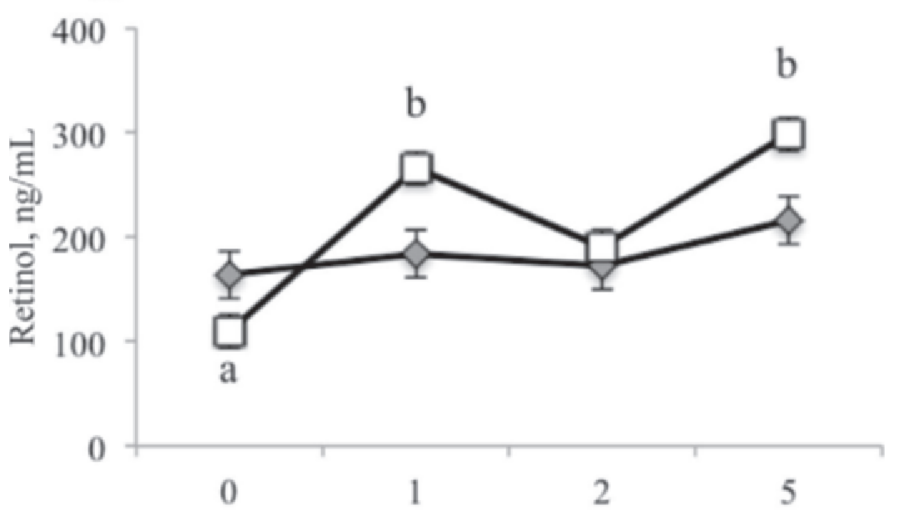

c.

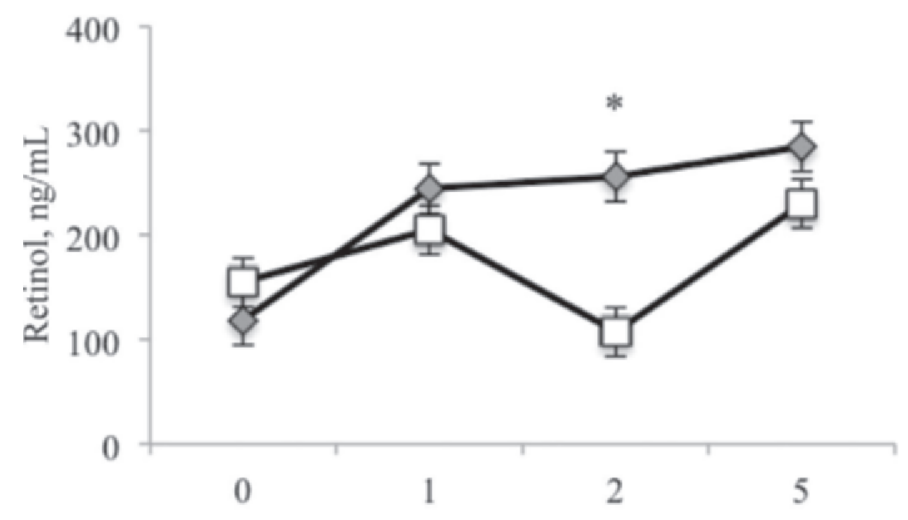

Time, wk

Figure 4. Plasma retinol concentrations of calves during the experimental period. (a) Calves were fed all-milk diets formulated to support daily gains of 0.25 (LG) and $0.5(\mathrm{MG}) \mathrm{kg}$ and supplemented (S) or not supplemented (C) with vitamins A, D, and E, creating 4 treatment groups: LG-C $(\diamond)$, LG-S $(\boldsymbol{\square})$, MG-C $(\diamond)$, and MG-S $(\square)$. (b) Calves were supplemented (S) or not supplemented (C) with vitamins A, D, and E; C $(\diamond), S(\square)$. (c) Calves were fed all-milk diets formulated to support daily gains of 0.25 (LG) and 0.5 (MG) kg; LG ( $\bullet$ ), MG ( $\square)$. Means with different letters $(\mathrm{a}, \mathrm{b})$ are different $(P<0.05)$. An asterisk $(*)$ denotes means within the same week are different $(P$ $<0.05)$. Week 0 equals date of birth. Values are mean \pm SEM; $\mathrm{n}=32$.

\author{
Journal of Dairy Science Vol. 97 No. 6,2014
}


recovered by wk $5(298.4 \pm 23.0 \mathrm{ng} / \mathrm{mL}$; Figure 4b). Control calves exhibited no change in plasma retinol compared with wk 0 .

Retinol also was affected by a time-by-energy-treatment interaction. The LG calves exhibited elevated retinol concentrations relative to wk 0 by wk $1(P<0.01)$ and maintained elevated concentrations throughout the study $(P<0.005)$. However, MG calves exhibited lower retinol concentrations $(P<0.005)$ at wk 2 relative to LG calves (Figure 4c).

\section{Positive Acute-Phase Proteins}

Serum haptoglobin concentration was affected by a week-by-vitamin-treatment-by-energy-treatment interaction $(P=0.08$; Figure 5a). Both MG-S and MG-C calves demonstrated elevated haptoglobin concentrations at wk $1(P<0.05)$, but MG-C calves exhibited markedly higher $(P<0.005)$ serum haptoglobin concentrations at wk $2(1,045 \pm 154 \mu \mathrm{g} / \mathrm{mL})$ compared with other treatment groups. Throughout the study period, haptoglobin concentrations of calves in the other treatment groups were not different $(P<0.05)$ than wk 0 averages. The wk 0 average for all calves was $8.3 \pm$ $77.5 \mu \mathrm{g} / \mathrm{mL}$, and wk 0 averages were similar among all treatment groups. Overall, consumption of the MG diet caused higher $(P<0.05)$ serum haptoglobin concentration. The LG calves exhibited a mean haptoglobin concentration of $14.2 \pm 45.0 \mu \mathrm{g} / \mathrm{mL}$, whereas MG calves exhibited a mean concentration of $166.5 \pm 44.7 \mu \mathrm{g} / \mathrm{mL}$.

Serum amyloid A of calves in all treatment groups is shown in Figure 5b. Serum amyloid A was not affected by treatment group, but was affected by time. Week 0 concentration of SAA for all calves averaged $84.2 \pm$ $19.1 \mu \mathrm{g} / \mathrm{mL}$. Week 1 values were highest $(265.4 \pm 19.4$ $\mu \mathrm{g} / \mathrm{mL}$ ), before a consistent decrease to final wk 5 values that were similar to wk 0 values.

\section{Immunoglobulins}

Effects of treatments on plasma $\operatorname{IgG}_{1}$ concentrations are shown in Figure 6a. By wk 1, MG-S calves exhibited higher $(P<0.005)$ plasma $\operatorname{IgG}_{1}$ concentrations than did MG-C calves $(15.2 \pm 1.6$ vs. $4.8 \pm 1.6 \mu \mathrm{g} / \mathrm{mL})$. However, MG-C calves maintained similar concentrations to those of MG-S calves during the remainder of the study. The LG-S calves achieved numerically higher $(P>0.9)$ plasma $\mathrm{IgG}_{1}$ than did LG-C calves at wk 1 $(11.5 \pm 1.6$ vs. $9.8 \pm 1.6 \mu \mathrm{g} / \mathrm{mL})$. The $\mathrm{LG}-\mathrm{C}$ calves maintained similar plasma $\operatorname{IgG}_{1}$ concentrations to those of LG-S calves during all other weeks.

Plasma $\mathrm{IgG}_{2}$ concentrations were similar throughout the study for all treatment groups (Figure 6b). Concentrations never differed from the wk 0 mean (mean for all calves of $1.0 \pm 0.1 \mathrm{mg} / \mathrm{mL})$, but LG calves exhibited higher $(P<0.05)$ concentrations at wk $5(1.7 \pm$ $0.2 \mathrm{mg} / \mathrm{mL}$ ) than during wk 1 through 3. Plasma IgA concentrations were similar throughout the study for all treatment groups (Figure 6c), but were affected by time $(P<0.0001)$. Concentrations were highest at wk $0(3.3 \pm 0.4 \mathrm{mg} / \mathrm{mL})$, but were negligible by wk 2 and remained so until the end of the study.

Plasma IgM concentrations (Figure 6d) were similar among treatment groups, but were affected by a timeby-vitamin-treatment-by-energy-treatment interaction $(P=0.068)$. At wk 0 , IgM concentration was highest for MG-S calves $(2.0 \pm 0.2 \mathrm{mg} / \mathrm{mL})$ and lowest for LG-S calves $(0.9 \pm 0.2 \mathrm{mg} / \mathrm{mL})$. After wk 0 , weekly means for all groups were numerically lower and similar among treatment groups.

\section{Glucose and NEFA}

Effect of treatments on plasma glucose concentrations is shown in Figure 7a. Plasma glucose concentrations were not affected by treatment; however, they were influenced by time. Glucose was lowest at wk 0 $(93.5 \pm 4.5 \mathrm{mg} / \mathrm{dL})$ but was higher $(P<0.01)$ during wk 3 through 5 , peaking at wk $4(116.7 \pm 4.5 \mathrm{mg} / \mathrm{dL})$.

Concentrations of plasma NEFA were affected by a time-by-vitamin-treatment-by-energy-treatment interaction $(P<0.0005$; Figure $7 \mathrm{~b})$. Plasma NEFA were highest at wk 0 for all groups, with LG-C calves exhibiting numerically lower wk 0 concentrations than other treatment groups. Plasma NEFA were similar among groups after wk 0 and were usually under $300 \mu \mathrm{Eq} / \mathrm{L}$ after wk 0 .

\section{DISCUSSION}

The current study explores whether $\alpha$-tocopherol demand increases with heightened caloric support for growth in preruminant calves. Results of our study indicate that supporting growth of $0.5 \mathrm{~kg}$ of $\mathrm{ADG}$ via whole milk potentiates an immune challenge that increases demand for $\alpha$-tocopherol as well as $25-(\mathrm{OH})$ vitamin $\mathrm{D}$ and retinol.

In the present study, growth rate is the best indicator of limiting nutrients. The MG diet was formulated to support BW gain of $0.5 \mathrm{~kg} / \mathrm{d}$, and the LG diet was formulated to support BW gain of $0.25 \mathrm{~kg} / \mathrm{d}$. In our study, both the LG-S and LG-C treatments were effective in supporting the formulated growth rate, indicating that dietary energy was limiting and not vitamin status. The MG-S treatment also supported the formulated growth rate, but the MG-C diet only supported a gain of $0.41 \pm 0.03 \mathrm{~kg} / \mathrm{d}$. The difference between ADG of MG-S and MG-C calves $(0.063 \pm 0.039 \mathrm{~kg})$ represents 
a.

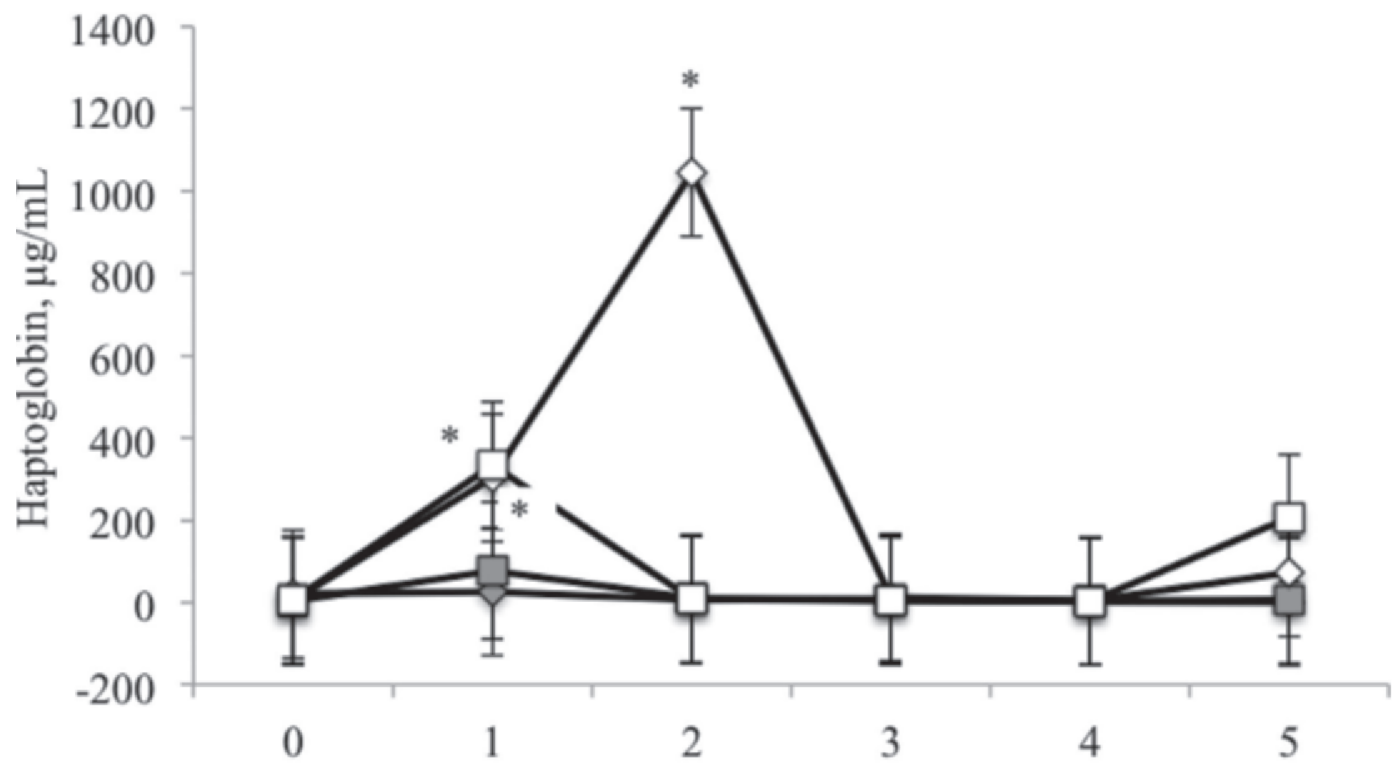

b. Time, wk

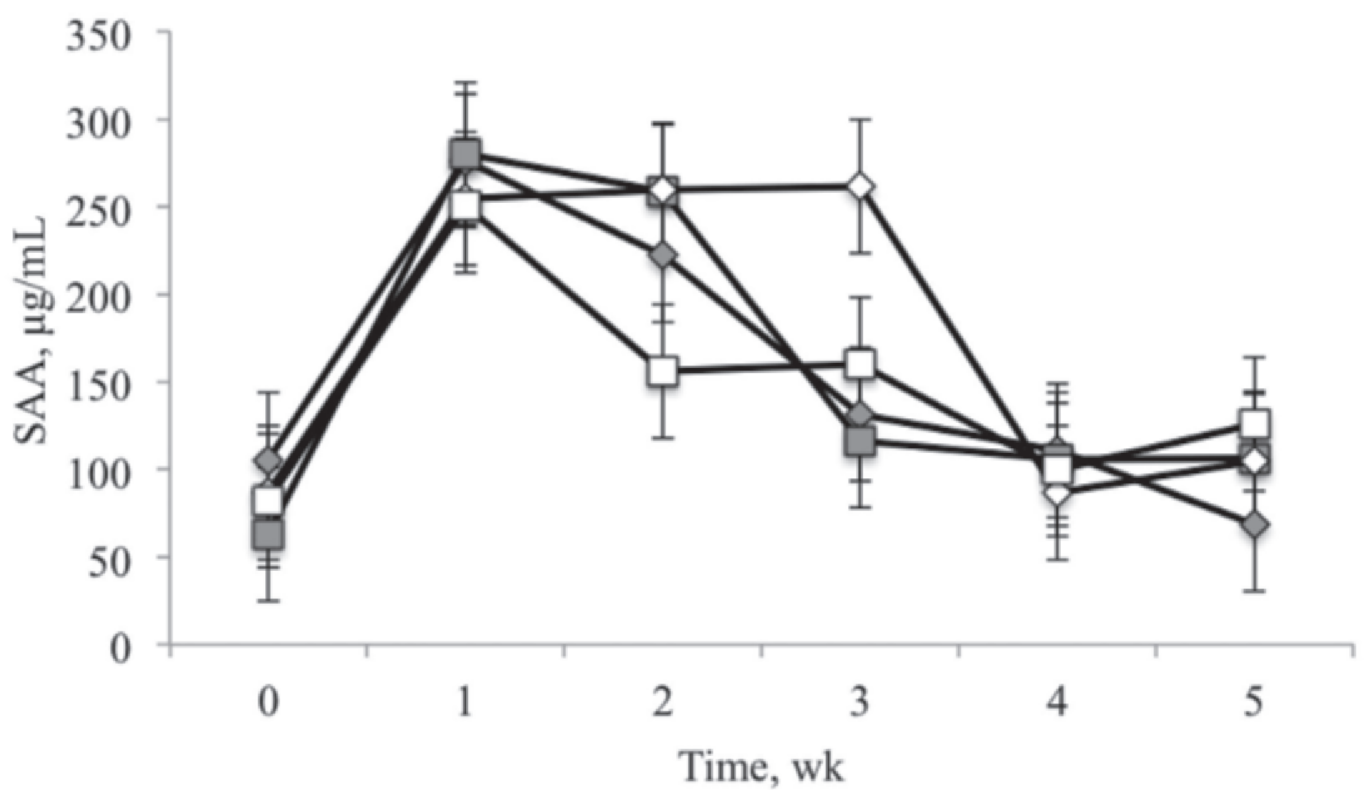

Figure 5. Serum (a) haptoglobin and (b) serum amyloid A (SAA) concentrations of calves during the experimental period. Calves were fed all-milk diets formulated to support daily gains of 0.25 (LG) and 0.5 (MG) $\mathrm{kg}$ and supplemented (S) or not supplemented (C) with vitamins A, D, and E, creating 4 treatment groups: LG-C $(\diamond)$, LG-S $(\square)$, MG-C $(\diamond)$, and MG-S $(\square)$. An asterisk $(*)$ denotes mean is different from wk 0 mean within treatment group $(P<0.05)$. Values are mean $\pm \mathrm{SEM} ; \mathrm{n}=32$.

a remarkable result considering the small sample sizes and brief duration of the feeding trial, which was approximately one-half of a standard preweaning feed period. Results of the current study suggest that fatsoluble vitamin status limited growth in MG-C calves. The identification of fat-soluble vitamins as limiting is crucial, because calf-rearing programs commonly use whole milk instead of vitamin-supplemented milk replacer as a staple in calf diets.

The potential for vitamin-limiting status in nonsupplemented commercial calf diets is first supported by the plasma $\alpha$-tocopherol statuses of calves in the present study. Supplemented calves consistently exhibited plasma $\alpha$-tocopherol concentrations that were 
a.

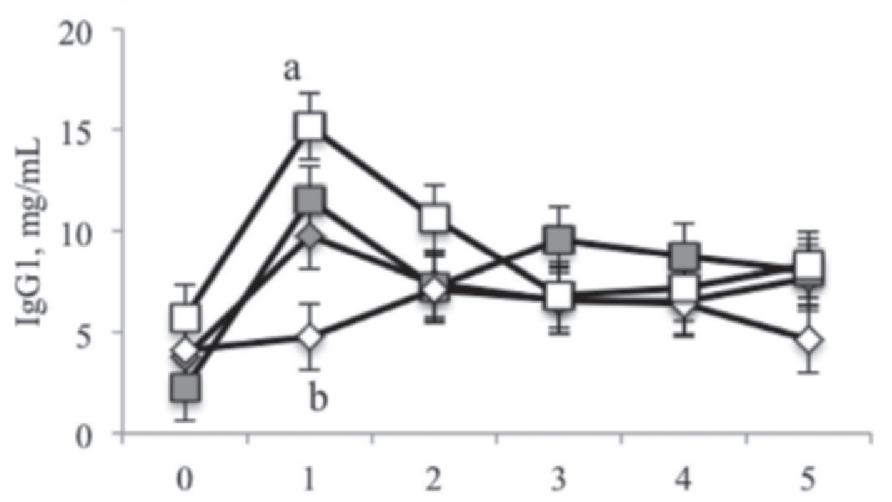

c.

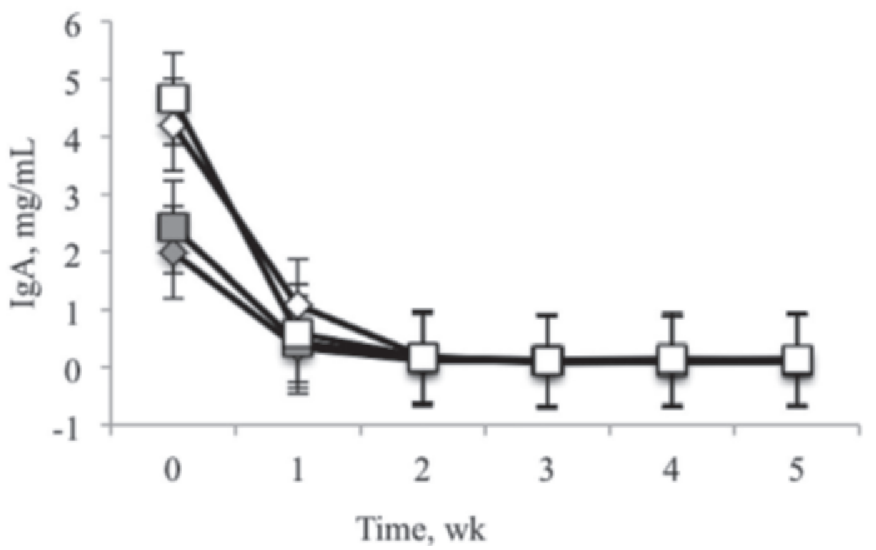

b.

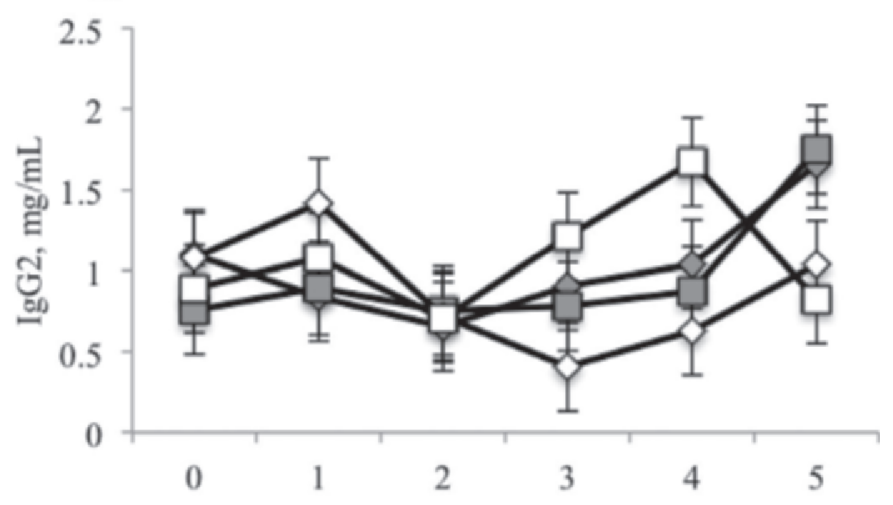

d.

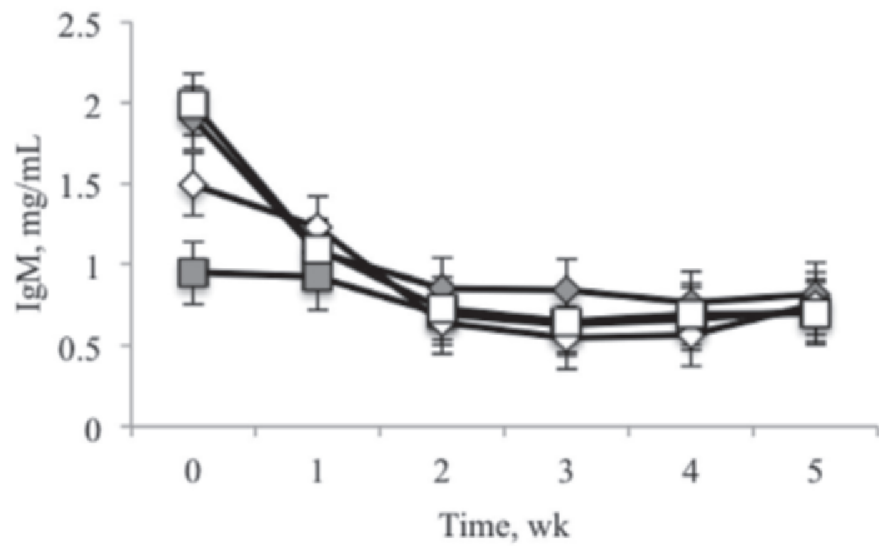

Figure 6. Serum (a) $\operatorname{IgG}_{1}$, (b) $\operatorname{IgG}_{2}$, (c) IgA, and (d) IgM concentrations of calves during the experimental period. Calves were fed all-milk diets formulated to support daily gains of 0.25 (LG) and 0.5 (MG) $\mathrm{kg}$ and supplemented (S) or not supplemented (C) with vitamins A, D, and E, creating 4 treatment groups: LG-C $(\diamond)$, LG-S $(\square)$, MG-C $(\diamond)$, and MG-S $(\square)$. Means without a common letter $(\mathrm{a}, \mathrm{b})$ are different $(P<0.05)$; values are mean \pm SEM; $\mathrm{n}=32$.

higher than those of the other treatment groups. Provision of caloric support for growth via the MG diet, however, decreased plasma $\alpha$-tocopherol status overall, and MG-S calves exhibited $\alpha$-tocopherol utilization at wk 2. Even in nonsupplemented calves, $\alpha$-tocopherol concentrations in MG calves were approximately half those in LG calves, indicating a greater vitamin demand regardless of dietary vitamin support. Neither fecal $\alpha$-tocopherol excretion nor tissue $\alpha$-tocopherol uptake was measured, but plasma concentrations suggest that tissue $\alpha$-tocopherol uptake increased when calves were fed the MG diet. Therefore, the increased $\alpha$-tocopherol demand induced by the MG diet and lower growth of MG-C calves suggests limiting dietary $\alpha$-tocopherol. Our results are validated by Nonnecke et al. (2010), who observed $\alpha$-tocopherol utilization in calves that achieved growth rates of $1.16 \mathrm{~kg} / \mathrm{d}$ relative to calves fed for maintenance requirements. Thus, the results support the need for further investigation of the relationship between $\alpha$-tocopherol and tissue accretion.
The best-known role of $\alpha$-tocopherol is that of an antioxidant. Postabsorptively, $\alpha$-tocopherol is incorporated by tocopherol-associated proteins into lowdensity lipoprotein and then dispersed throughout cells and cell membrane phospholipids (Azzi et al., 2002). $\alpha$-Tocopherol scavenges reactive oxygen species by donating a hydrogen atom from the hydroxyl group located on the terminal aromatic ring, thereby interrupting radical chain reactions (Sies and Murphy, 1991; Engin, 2009). The subsequent tocopherol radical is positioned away from the membrane and toward the aqueous portion of the cell, which allows intracellular reduction by ascorbate (vitamin C), glutathione, and NADPH (Sies and Murphy, 1991; Engin, 2009). In addition to sparing both glutathione and NADPH, as these molecules would otherwise be consumed in radical chain reactions, the antioxidative properties of $\alpha$-tocopherol ultimately prevent membrane lipid peroxidation and cell dysfunction caused by radicals, such as superoxide $\left(\mathrm{O}_{2}{ }^{-}\right)$and peroxynitrite $\left(\mathrm{ONOO}^{-}\right)$, and moderate downstream 


\section{a.}
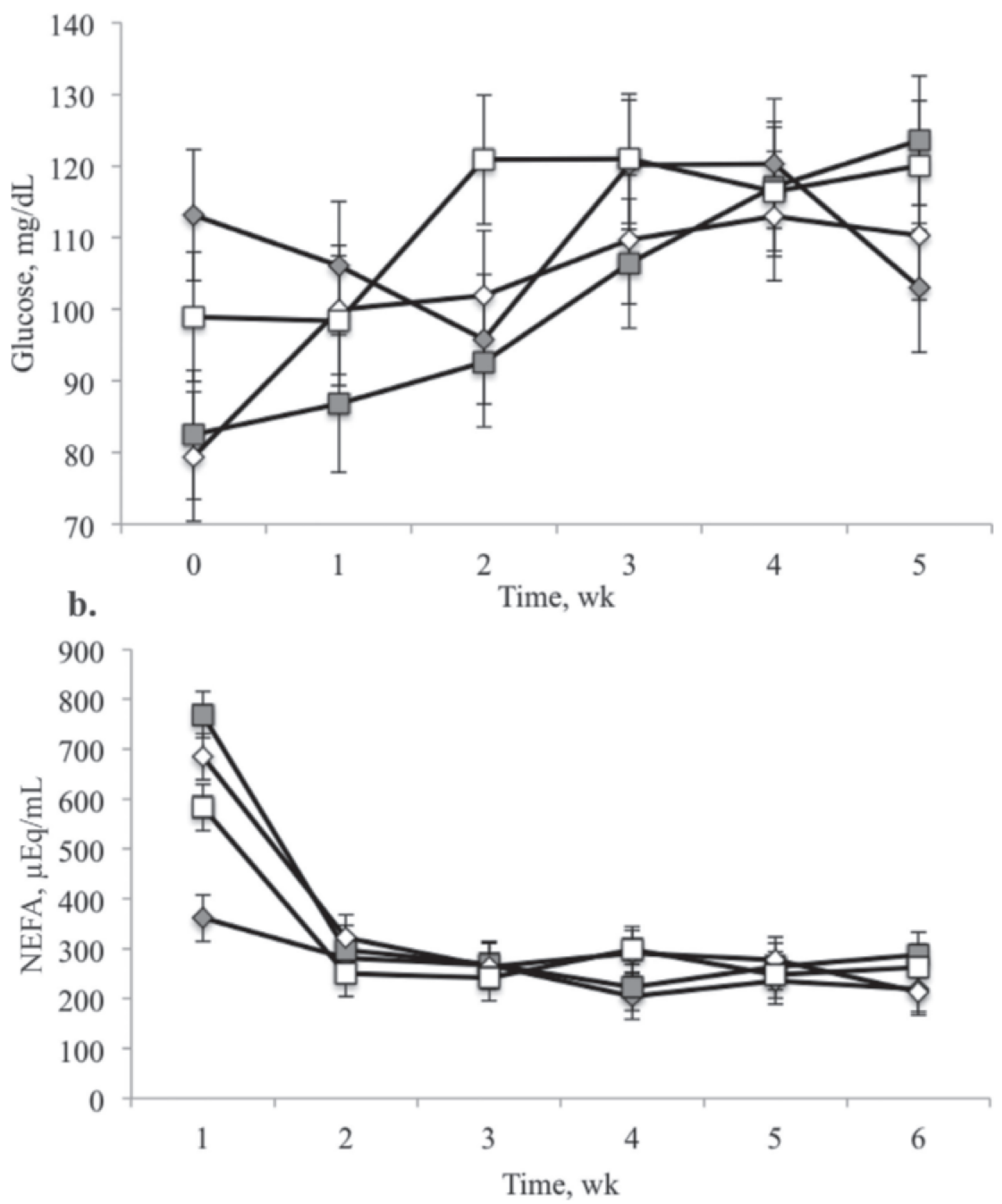

Figure 7. Plasma glucose (a) and NEFA (b) concentrations of calves during the experimental period. Calves were fed all-milk diets formulated to support daily gains of 0.25 (LG) and 0.5 (MG) $\mathrm{kg}$ and supplemented (S) or not supplemented (C) with vitamins A, D, and E, creating 4 treatment groups: LG-C $(\diamond)$, LG-S $(\square)$, MG-C $(\diamond)$, and MG-S $(\square)$. Values are mean \pm SEM; $\mathrm{n}=32$.

proinflammatory cytokine signaling (Szabó et al., 2007; Traber and Atkinson, 2007; Rubbo et al., 2009).

Supplementation of $\alpha$-tocopherol to calves in the current study resulted in accumulation of $\alpha$-tocopherol in plasma, suggesting steady saturation of tissues with the antioxidant. The increased $\alpha$-tocopherol utilization at wk 2 in MG-S calves coincided with increased serum haptoglobin and SAA in MG-C calves. Both molecules are positive acute-phase proteins; haptoglobin is specifically associated with oxidative burst and phagocytic activity of macrophages and neutrophils (Oh et al., 1990; Berkova et al., 1999) and SAA enhances highdensity lipoprotein binding by macrophages during LPS neutralization (Kisilevsky and Subrahmanyan, 
1992). Diarrhea and decreased feed intake were observed in 7 of 8 MG-C calves during wk 2 , but in only 2 of 8 MG-S, 1 of 8 LG-C, and 1 of 8 LG-S calves. The MG diet may have contributed to osmotic diarrhea in very young calves (wk 1 and 2) by providing highly digestible nutrients, such as lactose, to the lumen of the small intestine in excess of absorptive capacity. Lower incidence in MG-S calves than MG-C calves, however, suggests that diarrhea was secretory rather than osmotic and strongly suggests enteric pathogen challenge. Proinflammatory signaling in response to enteric challenge may have been moderated by $\alpha$-tocopherol. Suppression of growth then may have been a secondary effect of energy expenditure and decreased feed intake associated with the innate immune response.

25-(OH)-Vitamin D and retinol statuses before and at wk 2 may have further influenced susceptibility of calves to enteric challenge. Concentrations of $25-(\mathrm{OH})$-vitamin $\mathrm{D}$ in plasma between 25 and $30 \mathrm{ng} / \mathrm{mL}$ is recognized as the threshold for maintaining calcium-phosphorous homeostasis, but may be insufficient to support proper immune function (Nelson et al., 2012). Conversion of 25 - $(\mathrm{OH})$-vitamin D to $1,25-(\mathrm{OH})_{2}$-vitamin $\mathrm{D}$ has been observed in monocytes, macrophages, and B lymphocytes and is thought to influence T-regulatory cell responses by decreasing antigen-induced proliferation of these cells and subsequent proinflammatory signaling (Jeffery et al., 2009; Sun, 2010; von Essen et al., 2010). Vitamin D also increases Paneth cell antimicrobial peptide synthesis and subsequent autophagy of invasive luminal microbes (Fabri and Modlin, 2009; Yuk et al., 2009) and protects tight junction integrity (Kong et al., 2008).

In our study, calves exhibited dynamic concentrations of 25- $(\mathrm{OH})$-vitamin $\mathrm{D}$ in plasma because of the initial injection. Injected calves achieved concentrations of 25 - $(\mathrm{OH})$-vitamin $\mathrm{D}$ above threshold by wk 1 , but by wk 2 most calves exhibited concentrations below threshold for immune sustenance. Control calves were deficient from birth and were below even the accepted threshold for calcium and phosphorous homeostasis during the entire 5-wk study. The control calves likely were highly susceptible to enteric challenge by wk 2 . One important conclusion derived from these results dictates that milk diets alone do not provide adequate 25-(OH)-vitamin $\mathrm{D}$ for sustenance of physiologically normal immune activity. Milk replacer is often supplemented with more than $10,000 \mathrm{IU} / \mathrm{kg}$ of vitamin $\mathrm{D}_{3}$, whereas vitamin $\mathrm{D}_{3}$ content in whole milk approximates $300 \mathrm{IU} / \mathrm{kg}$ (NRC, 2001; Foote et al., 2007). Accordingly, calves fed milk replacer diets commonly achieve and maintain $25-(\mathrm{OH})$ vitamin $\mathrm{D}$ concentrations in plasma of between 40 and $70 \mathrm{ng} / \mathrm{mL}$ (Nelson et al., 2012), whereas calves in our study fed whole milk exhibited a decline to less than
$20 \mathrm{ng} / \mathrm{mL}$ when not supplemented beyond an initial injection.

Retinol also is known to affect intestinal health. Retinol-binding protein and transthyretin are known to be negative acute-phase proteins, and retinol deficiency during acute inflammation has been linked to decreased mucin gene expression in the intestinal epithelium (Mamoru et al., 2000). In our study, MG calves exhibited both a decrease in plasma retinol at wk 2 and an increase in serum haptoglobin. It is unknown whether inflammation caused retinol loss or whether the inverse is true, as is the state of intestinal integrity during the apparent enteric challenge at wk 2 . The combined known physiological effects of retinol and vitamin D deficiencies, however, may have contributed to increased susceptibility of calves to lumen pathogen.

The numerous immunological interactions of $\alpha$-tocopherol, vitamin $\mathrm{D}$, and retinol recorded in the literature demonstrate that the immune responses and slow growth exhibited by MG-C calves in the present study cannot be accounted for by one mechanism. The poor growth of MG-C calves relative to MG-S calves, however, strongly suggests that $\alpha$-tocopherol, vitamin $\mathrm{D}$, and retinol all moderated immune defenses in calves supported calorically for $0.5 \mathrm{~kg}$ of gain per day. Similar observations of immune responses have been documented in calves fed for variable growth rates. Foote et al. (2007) described lower T-lymphocyte viability in high-growth calves that were calorically supported for $1.2 \mathrm{~kg}$ of gain per day, but not in calves calorically supported for $0.55 \mathrm{~kg}$ of gain per day. Calves in that study were fed milk replacer supplemented with vitamins A, $\mathrm{D}$, and $\mathrm{E}$ at $44,092,11,023$, and $220 \mathrm{IU} / \mathrm{kg}$ of DM, respectively. That rate of vitamin supplementation corresponds to greater dietary vitamins $\mathrm{A}$ and $\mathrm{D}$ than diets in our study but corresponds to approximately $66 \%$ of vitamin E supplementation. Furthermore, the bioavailability of vitamin $\mathrm{E}$ in milk replacer (DL- $\alpha$-tocopheryl acetate) may have been lower than our supplementation with D- $\alpha$-tocopherol. Despite the dramatically higher supplementation of vitamins A and D, Foote et al. (2007) reported similar rates of clinical illness in high growth calves compared with our study. The high growth calves in the study by Foote et al. (2007) also exhibited decreased viability of $\mathrm{CD} 4^{+}, \mathrm{CD} 8^{+}$, and $\gamma \delta \mathrm{TCR}^{+} \mathrm{T}$ cells in culture and greater nitric oxide production by mononuclear leukocytes relative to controls. Taken in context with the previously discussed immunomodulatory mechanisms of vitamins D and $\mathrm{E}$, results reported by Foote et al. (2007) and Nonnecke et al. (2010) support the hypothesis that vitamin E demand increases as dietary energy increases and that the effects of deficiency on cell-mediated immune responses are negative. 
Plasma NEFA observed in the present study are consistent with observations reported in other literature (Stanley et al., 2002; Foote et al., 2007). Tumor necrosis factor- $\alpha$, IFN- $\gamma$, and an array of other cytokines are known to induce adipose tissue lipolysis and hepatic very low-density lipoprotein export during acute inflammation (Khovidhunkit et al., 2004). The theorized increase in very low-density lipoprotein export and adipose tissue lipolysis could account for the increased $\alpha$-tocopherol demand demonstrated by MG calves. Tocopherol-associated proteins are incorporated into lowdensity lipoprotein to transport $\alpha$-tocopherol to tissues. Although improved low-density lipoprotein transport is a possible mechanism for $\alpha$-tocopherol utilization, the theorized NEFA elevation that is characteristic of acute inflammation was not observed in our study. Therefore, our results are inconclusive regarding an inflammatory low-density lipoprotein-mediated mechanism for $\alpha$-tocopherol transport.

A large amount of data regarding passive transfer of maternal antibodies has been reported similar to our study. Robison et al. (1988) reported a higher mortality rate and lower growth rate when Holstein heifers failed to demonstrate a minimum of $12 \mathrm{mg}$ of total Ig per milliliter of serum between 24 and $48 \mathrm{~h}$ after birth. Numerous other studies have connected colostrum deprivation and failure of passive transfer to increased scouring rates, lower growth rates, and higher mortality. Besser et al. (1988a,b) demonstrated $\mathrm{Ig}_{1}$ clearance from circulation to the gastrointestinal lumen and identified $\operatorname{IgG}_{1}$ as the primary isotype of enteric rotavirus antibody. Immunoglobulin A has been studied less extensively than IgG in calves. In humans, the newborn consumes secretory $\operatorname{Ig} \mathrm{A}$ that acts in the intestinal mucosa. Secretory IgA is produced maternally via the entero-mammaric link, whereby $\mathrm{M}$ cells of intestinal Peyer's patches transport antigen to $\mathrm{T}$ and $\mathrm{B}$ lymphocytes that migrate to mammary glands according to lactogenic hormone influence (Hanson, 1998).

In our study, although all calves received identical amounts of colostrum, MG-C calves achieved lower $\mathrm{IgG}_{1}$ in plasma than MG-S calves by wk 1 (Figure 6a). Despite lower $\operatorname{IgG}_{1}$, the average total Ig observed in MG-C calves by wk 1 approximated the threshold described by Robison et al. (1988). Furthermore, MG-C calves demonstrated adequate serum $\operatorname{IgA}$ at wk 0 and the highest circulating $\operatorname{IgG}_{2}, \operatorname{IgA}$, and $\operatorname{IgM}$ of the 4 treatment groups at wk 1 (Figures 6a, b, and c, respectively). The heat treatment associated with pasteurization of dietary milk likely denatured most dietary $\operatorname{IgA}$; so, any effect of dietary IgA in enteric immunity is unlikely, and IgA observed at wk 1 is attributed to passive transfer. Therefore, our results indicate a potential role of neonatal vitamin supplementation in passive
Ig transfer. Given the previously discussed effects of vitamins $\mathrm{A}$ and $\mathrm{D}$ on intestinal health, decreased Ig utilization for neutralization of enteric pathogens during the first week postpartum, rather than improved passive transfer, should be explored as a potential benefit of neonatal vitamin supplementation. The potential effects of neonatal vitamin supplementation have been indirectly demonstrated in literature focusing on passive immunity in the porcine neonate. Specifically, IgG status in the porcine neonate is improved when late gestation dams are supplemented with vitamins A, C, and E (Rooke and Bland, 2002). Further work is required to separate the effects of vitamins $\mathrm{E}, \mathrm{A}$, and $\mathrm{D}$ on $\mathrm{IgG}_{1}$ transfer in our study and to elucidate whether vitamin status affects passive antibody transfer in the bovine neonate.

\section{CONCLUSIONS}

In conclusion, parenteral and oral supplementation with RRR- $\alpha$-tocopherol was effective in elevating $\alpha$-tocopherol in serum. The diets used in our study allowed for separate evaluation of energy- and vitaminlimited performance, as demonstrated by the growth patterns of the 4 treatment groups. The antioxidative role of $\alpha$-tocopherol and the interactive immunoregulatory functions of vitamins $\mathrm{E}, \mathrm{A}$, and D likely account for the higher growth rate of MG-S calves relative to MG-C calves and for the acute inflammatory response observed in MG-C calves at wk 2. Furthermore, vitamin E requirements may be increased by a proinflammatory state possibly associated with high growth rate. Neonatal vitamin supplementation may protect passive immunoglobulin transfer, but further work is required to separate the effects of $\alpha$-tocopherol, retinol, and 25- $(\mathrm{OH})$-vitamin $\mathrm{D}_{3}$. Overall, the current study provides evidence that supplementation with vitamins $\mathrm{E}, \mathrm{A}$, and D improves the growth and health of preruminant calves.

\section{ACKNOWLEDGMENTS}

The authors thank Stuart Products Inc. (Bedford, TX) for providing funds in support of the study and for the assistance of Tracy Porter of the Ruminant Diseases and Immunology Research Unit, National Animal Disease Center, USDA, Agricultural Research Service (Ames, IA), in running immunoglobulin isotype and positive acute-phase protein analyses. We are also grateful to the Iowa State University Dairy Farm (Ames) managerial staff, especially Joe Detrick, Mary Healey, and Lucas Schau for their dedication to the project through its completion and for their assistance at critical hours. Finally, we recognize the team 
of student employees at Iowa State University who contributed their time and efforts to calf operations and ultimately to the success of the project, including Meredith Stabel and Katie Fober.

\section{REFERENCES}

Azzi, A., R. Ricciarelli, and J. Zingg. 2002. Non-antioxidant molecular functions of $\alpha$-tocopherol (vitamin E). FEBS Lett. 519:8-10.

Berkova, N., C. Gilbert, S. Goupil, J. Yan, V. Korobko, and P. Naccache. 1999. TNF-induced haptoglobin release from human neutrophils: Pivotal role of the TNF p55 receptor. J. Immunol. 162:6226-6232.

Besser, T. E., C. C. Gay, T. C. McGuire, and J. F. Evermann. 1988a. Passive immunity to bovine rotavirus infection associated with transfer of serum antibody into the intestinal lumen. J. Virol. 62:2238-2242.

Besser, T. E., T. C. McGuire, C. C. Gay, and L. C. Pritchett. 1988b. Transfer of functional immunoglobulin G (IgG) antibody into the gastrointestinal tract accounts for IgG clearance in calves. J. Virol. 62:2234-2237.

Blome, R. M., J. K. Drackley, F. K. McKeith, M. F. Hutjens, and G. C. McCoy. 2003. Growth, nutrient utilization, and body composition of dairy calves fed milk replacers containing different amounts of protein. J. Anim. Sci. 81:1641-1655.

Diaz, M. C., M. E. Van Amburgh, J. M. Smith, J. M. Kelsey, and E. L. Hutten. 2001. Composition of growth of Holstein calves fed milk replacer from birth to 105-kilogram body weight. J. Dairy Sci. 84:830-842.

Engin, K. N. 2009. Alpha-tocopherol: Looking beyond an antioxidant. Mol. Vis. 15:855-860.

Fabri, M., and R. L. Modlin. 2009. A vitamin for autophagy. Cell Host Microbe 6:201-203.

Foote, M. R., B. J. Nonnecke, D. C. Beitz, and W. R. Waters. 2007. High growth rate fails to enhance adaptive immune responses of neonatal calves and is assocated with reduced lymphocyte viability. J. Dairy Sci. 90:404-417.

Hanson, L. A. 1998. Breastfeeding provides passive and likely longlasting active immunity. Ann. Allergy Asthma Immunol. 81:523533.

Hollis, B. W., J. Q. Kamerud, S. R. Selvaag, J. D. Lorenz, and J. L. Napoli. 1993. Determination of vitamin D status by radioimmunoassay with an ${ }^{125}$ I-labeled tracer. Clin. Chem. 39:529-533.

Jeffery, L. E., F. Burke, M. Mura, Y. Zheng, O. S. Qureshi, M. Hewison, L. S. K. Walker, D. A. Lammas, K. Raza, and D. M. Sansom. 2009. 1,25-Dihydroxyvitamin $\mathrm{D}_{3}$ and IL-2 combine to inhibit T cell production of inflammatory cytokines and promote development of regulatory T cells expressing CTLA-4 and FoxP3. J. Immunol. 183:5458-5467.

Jensen, S. K., and C. Lauridsen. 2007. $\alpha$-Tocopherol stereoisomers. Vitam. Horm. 76:281-308.

Khovidhunkit, W., M. Kim, R. Memon, J. Shigenaga, A. Moser, K. Feingold, and C. Grunfeld. 2004. Thematic review series: The pathogenesis of atherosclerosis. Effects of infection and inflammation on lipid and lipoprotein metabolism mechanisms and consequences to the host. J. Lipid Res. 45:1169-1196.

Kisilevsky, R., and L. Subrahmanyan. 1992. Serum amyloid A changes high density lipoprotein's cellular affinity. A clue to serum amyloid A's principal function. Lab. Invest. 66:778-785.

Kong, J., Z. Zhang, M. W. Musch, G. Ning, J. Sun, J. Hart, M. Bissonnette, and Y. C. Li. 2008. Novel role of the vitamin D receptor in maintaining the integrity of the intestinal mucosal barrier. Am. J. Physiol. Gastrointest. Liver Physiol. 294:G208-G216.

Mamoru, T., S. Spurr-Michaud, A. Tisdale, and I. Gipson. 2000. Vitamin A deficiency alters the expression of mucin genes by the rat ocular surface epithelium. Investig. Ophthalmol. Visual Sci. $41: 82-88$.

Nelson, C. D., T. A. Reinhardt, J. D. Lippolis, R. E. Sacco, and B. J. Nonnecke. 2012. Vitamin D signaling in the bovine immune sys- tem: A model for understanding human vitamin D requirements. Nutrients 4:181-196. http://dx.doi.org/10.3390/nu4030181.

Nonnecke, B. J., M. R. Foote, B. L. Miller, D. C. Beitz, and R. L. Horst. 2010. Fat-soluble vitamin and mineral status of milk replacer-fed dairy calves: Effect of growth rate during the preruminant period. J. Dairy Sci. 93:2684-2690.

Nonnecke, B. J., M. R. Foote, J. M. Smith, B. A. Pesch, and M. E. Van Amburgh. 2003. Composition and functional capacity of blood mononuclear leukocyte populations from neonatal calves on standard and intensified milk replacer diets. J. Dairy Sci. $86: 3592-3604$

Nonnecke, B. J., W. R. Waters, J. P. Goff, and M. R. Foote. 2012. Adaptive immunity in the colostrum deprived calf: Response to early vaccination with Mycobacterium bovis strain bacille Calmette Guerin and ovalbumin. J. Dairy Sci. 95:221-239.

NRC. 2001. Nutrient Requirements of Dairy Cattle. Natl. Acad. Sci., Washington, DC.

Oh, S. K., N. Pavlotsky, and A. Tauber. 1990. Specific binding of haptoglobin to human neutrophils and its functional consequences. J. Leukoc. Biol. 47:142-148.

Robison, J. D., G. H. Stott, and S. K. DeNise. 1988. Effects of passive immunity on growth and survival in the dairy heifer. J. Dairy Sci. $71: 1283-1287$.

Rooke, J. A., and I. M. Bland. 2002. The acquisition of passive immunity in the newborn piglet. Livest. Prod. Sci. 78:13-23.

Rubbo, H., A. Trostchansky, and V. B. O'Donnell. 2009. Peroxynitrite-mediated lipid oxidation and nitration: Mechanisms and consequences. Arch. Biochem. Biophys. 484:167-172.

Sies, H., and M. E. Murphy. 1991. Role of tocopherols in the protection of biological systems against oxidative damage. J. Photochem. Photobiol. B 8:211-218.

Stahr, H. M. 1991. Pages 239-241 in Analytical Methods in Toxicology. John Wiley \& Sons Inc., New York, NY.

Stanley, C. C., C. C. Williams, B. F. Jenny, J. M. Fernandez, H. G. Bateman II, W. A. Nipper, J. C. Lovejoy, D. T. Gantt, and G. E. Goodier. 2002. Effects of feeding milk replacer once versus twice daily on glucose metabolism in Holstein and Jersey calves. J. Dairy Sci. 85:2335-2343.

Sun, J. 2010. Vitamin D and mucosal immune function. Curr. Opin. Gastroenterol. 26:591-595.

Szabó, C., H. Ischiropoulos, and R. Radi. 2007. Peroxynitrite: Biochemistry, pathophysiology and development of therapeutics. Nat. Rev. Drug Discov. 6:662-680.

Tikofsky, J. N., M. E. Van Amburgh, and D. A. Ross. 2001. Effect of varying carbohydrate and fat content of milk replacer on body composition of Holstein bull calves. J. Anim. Sci. 79:2260-2267.

Traber, M. G., and J. Atkinson. 2007. Vitamin E, antioxidant and nothing more. Free Radic. Biol. Med. 43:4-15.

Voljc, M., T. Frankic, A. Levart, M. Nemec, and J. Salobir. 2011. Evaluation of different vitamin $\mathrm{E}$ recommendations and bioactivity of $\alpha$-tocopherol isomers in broiler nutrition by measuring oxidative stress in vivo and the oxidative stability of meat. Poult. Sci. 90:1478-1488.

von Essen, M. R., M. Kongsbak, P. Schjerling, K. Olgaard, N. Odum, and C. Geisler. 2010. Vitamin D controls T cell antigen receptor signaling and activation of human $\mathrm{T}$ cells. Nat. Immunol. 11:344-349.

Weiser, H., and M. Vecchi. 1981. Stereoisomers of $\alpha$-tocopheryl acetate. II. Characterization of samples by physic-chemical methods and determination of biological activities in the rat resorptiongestation tests. Int. J. Vitam. Nutr. Res. 51:100-113.

Weiser, H., and M. Vecchi. 1982. Stereoisomers of $\alpha$-tocopheryl acetate. II. Biopotencies of all eight stereoisomers, individually or in mixtures, as determined by rat resorption-gestation tests. Int. J. Vitam. Nutr. Res. 52:351-370.

Yuk, J. M., D. M. Shin, H. M. Lee, C. S. Yang, H. S. Jin, K. K. Kim, Z. W. Lee, S. H. Lee, J. M. Kim, and E. K. Jo. 2009. Vitamin $D_{3}$ induces autophagy in human monocytes/macrophages via cathelicidin. Cell Host Microbe 6:231-243. 